\title{
Economic Analysis of Fish Farming in Calabar, Cross River State, Nigeria
}

\section{${ }^{1}$ Ideba E. Ele, ${ }^{\star 2}$ Otu W. Ibok, ${ }^{3}$ Essien A. Antia-Obong, ${ }^{1}$ Iniobong E. Okon, and ${ }^{2}$ Ekaette S. Udoh}

${ }^{1}$ Department of Agricultural Economics and Extension, University of Calabar, P.M.B 1115, Calabar.

2Department of Agricultural Economics and Resources Management, Akwa lbom State University, Obio Akpa Campus, P.M.B 1167, Uyo, Akwa Ibom State.

${ }^{3}$ Department of Economics, Akwa Ibom State University, Obio Akpa Campus, P.M.B 1167, Uyo, Akwa Ibom State.

Article No.: 061013653

DOI: 10.15580/GJAS.2013.7.061013653

Submitted: 10/06/2013

Accepted: $22 / 07 / 2013$

Published: 29/07/2013

${ }^{\star}$ Corresponding Author

Otu W. Ibok

E-mail: otuibok@yahoo.com

Phone: +2348035914329

Keywords:

Fish farming, cost, gross margin,

production function, Calabar,

aquaculture
The study was on economic analysis of fish farming in Calabar, Cross River State, Nigeria. It determined the factors affecting fish farming, estimated gross margin of fish farms and examined the costs and returns relationship of fish farming in the study area. The study utilized a two stage sampling technique to select 36 fish farms in Calabar. The study revealed that the major constraints affecting increased level of output in the study area were high cost of inputs, lack of adequate finance, access to credit facilities, security and farm labour problems. Fish farming in the study area is profitable as majority of the farmers made a gross margin of N400, 000- N700, 000 per annum. It was also discovered that the amount spent on stocking accounted for $37.27 \%$ of the running cost, followed by amount spent on water $(30.21 \%)$, feeding (16.51\%) and labour (14.84\%). Multiple regression analysis was used to analyze the data. Cob-Douglas equation was chosen to be the lead equation because of statistical significance of the coefficient and high $\mathbf{R}^{2}$ value of 0.94 . The result indicated that feed $(\mathrm{kg})$, years of farming experience and stocking density have significant effect on output levels. The study recommends among others, that fish hatcheries and feed mill should be established in the study area. 


\section{$1.0 \quad$ INTRODUCTION}

Despite fluctuations in supply and demand caused by the changing state of fisheries resources, the economic climate and environmental conditions, fisheries including aquaculture have traditionally been and remain an important source of food, employment and revenue in many countries and communities. After the remarkable increases in both marine and inland capture of fish during the 1950s and 1960s, world fisheries production has leveled off since the 1970s. This leveling off of the total catch follow the general trends of most of the world fishing areas, which have apparently reached their maximum potential for fisheries production, with the majority of stocks being fully exploited. It is therefore very unlikely that substantial increase in total catch will be obtained in the future. In contrast, aqua-cultural production has followed the opposite path. Starting from an insignificant total production, inland and marine aquaculture production has been growing at a remarkable rate, offsetting part of the reduction in ocean catch of fish (WHO, 2007). Fish plays a vital role in feeding the world's population and contributing significantly to the dietary protein intake of hundreds of millions of the populace on a global scale. Almost 16 percent of total average intake of animal protein was attributed to fish in 1998 (FAO, 2003). In developing countries, fish is a highly acceptable food that supplies as much as 40 percent of all animal protein availability of the countries where fish is the main source of animal protein. About 39 out of the top 40 are found in the developing world. Moreover, the poor spend proportionally more on fish than on meat or other sources of animal protein. FAO fisheries report (2003) indicates that fish is very important in nutrition, as it provides vital nutrients and source of animal protein especially to the poor who are unable to purchase other more expensive sources such as beef, pork or chicken. The report estimated that capture fisheries feed about 17 million people at an average annual per capital consumption of $10 \mathrm{~kg}$. Antonio and Akinwumi (1991) and Slang (1973) verified that fish allows for protein improved nutrition in that it has a high biological value in terms of higher protein retention in the body, higher protein assimilation as compared to other animal protein sources, low cholesterol content and one of the safest sources of animal protein.

However, fisheries occupy a unique position in the agricultural sector of the Nigerian economy. In terms of Gross Domestic Product (GDP), the fishery sub-sector has recorded the fastest growth rate in agriculture to the GDP. The contribution of the fishery sub-sector to GDP at 2001 current factor cost rose from $\mathrm{N} 76.76$ billion to $\mathrm{N}$ 162.61 billion in 2005 (CBN Report,2005). Nigeria has a land area of $923,768 \mathrm{Km}^{2}$ with a continental shelf area of $47,934 \mathrm{Km}^{2}$ and a length of coast line of $853 \mathrm{Km}$. It also has a vast network of inland waters like rivers, flood plains, natural and manmade lakes and reservoirs
(Shimang, 2005). The inland water mass was estimated to be about 12.5 million hectares of inland waters capable of producing 512,000 metric tons of fish annually (Shimang, 2005). Despite these considerably high potentials, local fish production has failed to meet the country's domestic demand. The fish industry remains the most virgin investment in Nigeria compared with the importation of frozen fish in the domestic market (Ndu, 2006). The country demand for fish consumption is estimated at 1.4 million metric tones. However, a demand supply gap of at least 0.7 million metric tones exists nationally with import making up the short fall at a cost of almost 0.5 billion US dollars per year. Domestic fish production of about 500,000 metric tones is supplied by artisan fisher - folk (85\%), despite over fishing in many water bodies across the country (Adekoya and Miller, 2004).

\subsection{Statement of problem}

The performance of the fisheries sector in Nigeria is below expectation with low supply. This is evident in the fact that Nigeria still imports fish into the country to supplement fish production. According to the proceedings of the fisheries society of Nigeria (FISON), about $50 \%$ deficit supply of requirement is met through importation, which constitutes a huge avoidable drain of Nigeria's scare foreign exchange (Anko and Eyo, 2001). The contribution of domestic fish production to the country's fish sector cannot be over emphasized. Fish farming has the potential of contributing to domestic fish production and reducing the amount of money spent on fish importation. It is with this utmost importance that this study was carried out to investigate the viability and production constraints faced by fish farmers in the study area. Hence, this research will fill this gap and provide empirical information. The specific objectives of this study are to: access the socio-economic characteristics of fish farmers, determine the factors affecting fish farming, estimate the gross margin of fish farms and examine the cost and return relationship of fish farming in the study area.

\subsection{Review of relevant literature}

Number of studies has been reported on the economics of fish farming around the world. Elhendy and Alzoom (2001) assessed the cost of tilapia farming in central region of Saudi Arabia. The study showed that the minimum average cost of production occurs for 201 tonnes of tilapia per year per farm and profit is maximized for a production of 300 tonnes annually per farm. All farms operate at less than profit-maximizing scale and most operate at less than minimum efficient scale. Also, El-Naggar, Nasr-Alla, and Kareem (2008) examines the economics of fish farming in Behera Governorate of Egypt. They found out that, high prices of fish feed; declining fish prices and lack of finance were 
the top ranking serious constraints facing fish farmers in that area. Feed costs per $\mathrm{kg}$ of fish were LE 3.87, representing $58.9 \%$ of the production costs. The breakeven analysis showed that average production costs of LE 6.57 per kilogram of fish while the sales price is LE $7.5 / \mathrm{kg}$. The findings also reveal that quantity of fish seeds is a notable and significant factor contributing to the fish farming enterprise in the study area. Kassli, Baruwa and Mariama (2011) analyzed the economics of inland fishing, aquaculture and fish marketing in Niamey and Tillabery areas of Niger Republic. The study showed that both the aquaculture and inland fish production were profitable with a rate of return of $61 \%$ and $320 \%$ respectively while two types of fish marketing channels were identified. Yesuf et al. (2002) assessed the economics of fish farming in Ibadan Metropolis, Nigeria. The study revealed that most farmers with secondary education and above operate at small-scale level with an average of three (3) ponds. Fish farmers practiced polyculture fish farming. Clarias spp is the most raised fish species followed by Heteroclarias spp. The gross margin analysis revealed that medium scale farmers derived the highest return of $\mathrm{N} 1.55$ for every one naira expended. This is followed by large-scale farmers at $\mathrm{N}$ 1.52 for every 1 Naira compared with only $\mathrm{N} 1.34$ for every 1Naira spent by small-scale farmers. Ajao (2006), found that $80 \%$ of fish farmers in Oyo state, Nigeria, operated less than two (2) ha which could not capture economy of size. More than $90 \%$ of the respondents distributed their fish at the site while $60 \%$ had little access to extension agents. Meanwhile fish farming was found to be profitable. Kudi, Bako and Atala (2008) examined the resources, cost and returns and other factors affecting fish production in Kaduna State, Nigeria. The study revealed that land, water, labour and capital were the main resources employed in fish production. The costs and returns analysis indicated that, variable cost constituted $97.63 \%$ of the total cost of fish production in the study area, while the fixed cost constituted $2.37 \%$. Amongst the variable inputs, fingerlings/juveniles (42.82\%) and feed (34.70\%) constituted the highest $(77.52 \%)$ to cost of production, while hired labour constitutes $16.91 \%$. The cost of production was N571, 231.79, the total revenue of N5, $853,625.64$ and the net income was N5, 282, 393.85 indicating that fish production was highly profitable.

\subsection{MATERIALS AND METHOD}

\subsection{Description of Study area}

The research was carried out in Calabar consisting of Calabar South Local Government Area and Calabar
Municipal Local Government Area of Cross River State. Cross River State occupies an area of about 22,342.176 square kilometers (Quarterly News Letter of the Ministry of Local Government Affairs, C.R.S 2006). It is located on Latitude $5^{\circ} 25^{\circ} \mathrm{N}$ and longitude $25^{\circ} 0^{\circ} \mathrm{E}$. The soils of Cross River State are Ultisol and Alfisol but predominantly Ultisol, suitable for pineapple production. Cross River State is bounded on the North by Benue State, South by Bight of Bonny and in the East by Ebonyi and Abia States, while in the West by Republic of Cameroun (Menakaya and Floyd, 1978). About 2, 888, 966 people inhabit the area, of which the Efiks, Ejaghams and Bekwarras are the major ethnic groups (Agbor, 2007). Cross River State has the largest rainforest covering about 7, 290 square kilometers. It is described as one of Africa's largest remaining virgin forest harboring as many as five million species of animals, including insects and plants. The state is located within the evergreen rainforest zone. There are two distinct climate seasons in the area, rainy season, from March to October and dry season from November to February. The annual rainfall varies from 2, 942mm to $3,424 \mathrm{~mm}$. The average temperature is about $28^{\circ} \mathrm{C}$. Cross River State is characterized by the presence of numerous ecological and zoo-geographically important high gradient streams, rapids and waterfalls. Fishing and subsistence agriculture are the main occupations of the people. Crops grown in the locality include rice, maize, yam, cassava, pineapple, plantain, banana, oil palm, rubber and cocoa among others (Agbor, 2007).

\subsection{Sampling procedure and size}

A sampling frame consisting of all farmers in Calabar, Cross River State was gotten from the State Fisheries Department, Ministry of Agriculture. The sampling technique adopted comprised of two stage sampling procedure.

The first stage involves the purposive sampling of fish farms in two local government area of Cross River State, which were Calabar-South and CalabarMunicipality. The second stage involves the random sampling of 16 fish farms from each local government area, making a total of 36 farms for the study.

\subsection{Analytical technique}

Descriptive statistics such as frequency count and percentages were used to analyze the socio-economic characteristics of fish farmers. To estimate the gross margin of fish farmers in the study area, the following formula was used:

$\mathrm{GM}=\mathrm{TR}-\mathrm{TVC} \ldots \ldots \ldots \ldots \ldots \ldots \ldots 1$

Where GM = Gross Margin

$\mathrm{TR}=$ Total Revenue

TVC $=$ Total Variable Cost 
To determine the factors that affect the quantity of fish produced by fish farmers, different forms of production functions were fitted to the data, using Ordinary Least Square estimating method (Kouisoyiannis 1977). The
Cob-Douglas production function was chosen as the lead equation. Gujarati and Sangeetha (2007) gave the implicit model as:

$\log Y=b_{0}+b_{1} \log X_{1}+b_{2} \log X_{2}+b_{3} \log X_{3}+b_{4} \log X_{4}+U$ 2

For this study, the implicit function was estimated using variables affecting fish farming in the study area as follows:

$\log Q O F P=b_{0}+b_{1} \log L B+b_{2} \log F D+b_{3} \log F E+b_{4} \log S D+U$

Where QOFP = Quantity of fish produce in Kilograms

$\mathrm{LB}=$ Labour in Mandays

$\mathrm{FD}=$ Feed $(\mathrm{kg})$

$\mathrm{FE}=$ Farming experience (years)

$\mathrm{SD}=$ Stocking density (number of fish per pond size)

$\mathrm{U}=$ Error term

\subsection{RESULTS AND DISCUSSION}

Table I shows the results of the socio-economic characteristics of fish farmers in the study area. The results revealed that the males (81\%) are actively involved in fish farming than the females (19\%). This is in line with artisanal fishing, where fishing is male dominated (Ele, 2008). It also shows that the farmers that are actively involved in fish farming falls within 40 and 50 years and this means that the farmers still have the strength to run the business. All the respondents are learned and highly educated as all of them had attended tertiary education (100\%). This means that fish farming is a highly technical enterprise that requires learned farmers. The study also shows that the business can be operated as a part- time business. Majority of the farmers were civil servants $(50 \%)$, while others where traditional leaders $(11 \%)$, veterinary surgeons $(11 \%)$, business owners $(11 \%)$ and pensioners $(11 \%)$. This agrees with Adewuyi et al., (2010) as $79 \%$ of fish farmers were not full time farmers.

\section{Table I: Socioeconomic Characteristics of fish farmers}

\begin{tabular}{lll}
\hline Variable & Frequency & Percentage \\
\hline Sex: & & \\
Male & 29 & 81 \\
Female & 7 & 19 \\
Age: & $\mathbf{3 6}$ & $\mathbf{1 0 0}$ \\
$30-40$ & 7 & 20 \\
$41-50$ & 14 & 40 \\
$51-60$ & 11 & 30 \\
$61-70$ & 4 & 10 \\
Educational background & $\mathbf{3 6}$ & $\mathbf{1 0 0}$ \\
No formal Education & 0 & 0 \\
Primary Education & 0 & 0 \\
Secondary Education & 0 & 0 \\
Tertiary Education & 36 & 100 \\
& $\mathbf{3 6}$ & $\mathbf{1 0 0}$ \\
Full or Part Time: & & 11 \\
Full time farmer & 4 & 89 \\
Part time farmer & 32 & $\mathbf{1 0 0}$ \\
Occupation & $\mathbf{3 6}$ & 11 \\
Fish farmer & & 50 \\
Civil servant & 4 & 11 \\
Traditional leader & 18 & 11 \\
Veterinary surgeon & 4 & 11 \\
Business owner & 4 & 6 \\
Pensioner & 4 & $\mathbf{1 0 0}$ \\
& 2 &
\end{tabular}

Source: Field survey, 2011. 


\subsection{Core survey result}

Table II shows core survey results of fish farmers. The table shows that all the respondents in the study areas used intensive system (100\%) of farming. This is because the major motive of farmers is to make profit. Earthen pond (47\%) was mostly preferred followed by fibre glass pond (31\%) and concrete pond (30\%). Even though the concrete pond has the advantage of lasting over ten years and has lower dependence on climatic conditions (i.e. not drying up during the dry season when the water table is low). The earthen pond was preferred because of cheap sources of underground water from the inundated swamps. Fibre glass ponds were mostly used in combination with earthen pond. This was found in the Calabar-municipality as they do not require large land. Aquaculture, though gaining popularity, remained quite challenging. Consequently, the number of operational ponds per individual farmer were mostly on the small Size 2-4 (50\% of the respondents) Next ranked a minimum of 7 to 8 ponds per farm $(30 \%)$ owned by those farmers with larger funds, confirming that access to credit was essential for meaningful operations.

This result agrees with Yesuf et al., (2002). The major fish stocked was Clarias (Catfish) $61 \%$, followed by tilapia (Lady Fish) (32\%). A few practiced polyculture, mostly catfish with tilapia. Catfish serve as predators on the very small tilapia; catfish was mostly preferred in the study area because of its good taste, grows fast and gives high production in ponds. Chakroff (1975) stated that in Thailand, Clarias catfish yielded about $97,000 \mathrm{~kg} / \mathrm{ha}$ when they are fed supplementary foods. Thirty nine percent (39\%) of the farmers stocked between 700 and 950 fish per pond, 50\% stocked between 1000 and 1,500 fishes and $11 \%$ stocked more than 1,500 fishes. Apparently, this differ from the recommended stocking density of at least 1000 juveniles per square meter and 2 to 3 juveniles per square meter in earthen pond (LSADA, 2005). According to Chackroff (1975), tilapia fish can be stocked from 100 fish per hectare to about 50, 000 fish per hectare. Nevertheless, the more fish stocked, the more food must be available for best possible growth in pond.

Also table II shows that most feed used by the farmers are brought in from other states and are formulated $(81 \%)$. This increased the cost of feed. However, only $19 \%$ of the farmer used locally made feed. This substandard nutrient value and feeding patterns were contributing factors to high mortality rate before maturity. This result is in line with the findings of Adewuyi et al., (2010). Major constraints limiting improved output included cost of inputs $(27.1 \%)$, Finance (20.8\%), Theft by Labour (13.5\%), equipments (13.5\%), Land (10.4\%), Climatic variation (7.3\%) and water pollution/cost $(7.3 \%)$. This result agrees with the findings of El-Naggar, Nasr-Alla and Kareem (2008).

Tables II: Core survey results of fish farmers

\begin{tabular}{lll}
\hline Variable & Frequency & Percentage \\
\hline $\begin{array}{l}\text { Type of fish farm: } \\
\text { Intensive }\end{array}$ & 36 & 100 \\
Extensive & 0 & 0 \\
& 36 & 100 \\
Type of pond: & 17 & 47 \\
Earthen & 8 & 22 \\
Concrete & 11 & 31 \\
Fibre glass & 36 & 100 \\
Type of fish stocked: & 25 & 61 \\
Catfish (Clarias) & 13 & 32 \\
Tilapia & 2 & 7 \\
Snakehead & 36 & 100 \\
Stocking density per pond & & 39 \\
700-999 & 14 & 50 \\
1000-1500 & 18 & 11 \\
$>1500$ & 4 & $\mathbf{1 0 0}$ \\
& 36 & 19 \\
Source of feed: & & 81 \\
Local feed (Self Prepared) & 7 & 100 \\
Formulated feed & 29 & 20.8 \\
Production constraints: & 36 & 27.1 \\
Finance & & 13.5 \\
Cost of inputs & 20 & \\
Theft by labour & 26 &
\end{tabular}




$\begin{array}{lll}\text { Equipments } & 13 & 13.5 \\ \text { Land } & 10 & 10.4 \\ \text { Climate variation } & 7 & 7.3 \\ \text { Water } & 7 & 7.3 \\ & \mathbf{9 6} & \mathbf{1 0 0} \\ \text { Number of Ponds } & & \\ 2-4 & 18 & 50 \\ 5-6 & 7 & 20 \\ 7-8 & 11 & 30 \\ & \mathbf{3 6} & \mathbf{1 0 0}\end{array}$

Source: Field Survey, 2011. * Number exceeded the total of respondents because of multiple responses.

Table III shows that amount spent on water accounted for $30.21 \%$ of the running cost, feeding $(16.51 \%)$, stocking $(37.27 \%)$ and labour (14.84\%). The total amount spent on stocking accounted for $37.27 \%$ of the running cost, which is the highest cost of input. This is because there is no hatchery that produces fingerlings for the farmers. Therefore, fingerlings are brought from other states at a high cost. Consequently we have high demand for fingerlings and inadequate supply, resulting in increased price of fingerlings. Feeding accounted for only $16.51 \%$ of the running cost because most farmers used supplementary feed and substitute with formulated feed. Also, farmers that used earthen pond used fertilizer to encourage the growth of phytoplankton which the fish feed on. This result is in line with the finding of Kudi, Bako and Atala (2008); Elhendy and Alzoom (2001); and El-Naggar, Nasr-Alla and Kareem (2008).

\begin{tabular}{lc}
$\begin{array}{l}\text { Table III: Percentage contribution of variable input to cost } \\
\text { of production }\end{array}$ \\
\hline Inputs & Percentages \\
\hline Water & 30.21 \\
Feed & 16.51 \\
Stocking & 37.27 \\
Labour & 14.84 \\
\hline Total & $\mathbf{1 0 0} \%$ \\
\hline Sources: Field survey, 2011.
\end{tabular}

Table IV shows the profit and Gross margin of fish farmers. This indicate that majority of the farmers make a gross margin of $\$ 400,000-\$ 700,090$ (50\%) followed by 1 - $3.5 \mathrm{~m}(28 \%)$. This shows that the business is profitable according to the level of investment and variable cost minimization. The table also shows that only $11 \%$ of the respondent did not make profit but $89 \%$ of the respondent did make profit. This result is in consonant with the findings of Adewuyi et al., (2010); Elhendy and Alzoom (2001); Ajao, (2006); Kudi, Bako and Atala (2008); Yesuf et al., (2002); Kassali, Baruwa and Mariama (2011); and El-Naggar, Nasr-Alla and Kareem (2008).

Table IV: Gross margin and profit of fish farmers

\begin{tabular}{lll}
\hline Variable & Frequency & Percentage \\
\hline Gross Margin (N) & & \\
$<200,000$ & 4 & 11 \\
$200,000-300,000$ & - & - \\
$400,000-700,000$ & 18 & 50 \\
$1 \mathrm{M}-3.5 \mathrm{M}$ & 10 & 28 \\
$>3.5 \mathrm{~m}$ & 4 & 11 \\
Loss & - & - \\
& $\mathbf{3 6}$ & $\mathbf{1 0 0}$ \\
Profit (N) & 4 & $11 \%$ \\
Loss & 8 & 22 \\
$200,000-300,000$ & 10 & 28 \\
$400,000-700,000$ & 10 & 28 \\
$1 \mathrm{~m}-3.5 \mathrm{~m}$ & 4 & 11 \\
$>3,5 \mathrm{~m}$ & $\mathbf{3 6}$ & $\mathbf{1 0 0}$ \\
\end{tabular}

Source: field survey, 2011. 


\subsection{Regression Result}

Table $V$ shows the estimated production functions of fish farms in the study area. The Cobb - Douglas production function was chosen as the lead equation because of the statistical significance of the coefficient and the high Rsquare. $R^{2}$ (Coefficient of multiple determination) value of 0.94 connotes that $94 \%$ of the variability in quantity of fish produced in the study area is accounted for by the regressors included in the model. In addition, the $\mathrm{F}$ value was significant at $1 \%$ which means that the regression model is significant. The quantity of feed used in $\mathrm{Kg}$, was significant at $5 \%$ and had a positive relationship with output meaning that as feed $(\mathrm{Kg})$ used increases, output increases. Farming experience in years was significant at $5 \%$ and had a negative relationship with output, meaning that one could go into fish farming without much experience. Stocking density was significant at $1 \%$ level and had a positive relationship with output, meaning that as farmer uses the proper stocking density, output increases. The issues should be taken seriously by extension personnel who advise the farmer. This result also agrees with the findings of Adewuyi et al., (2010).

Table V: Estimated production functions of fish farms in Calabar using three functional forms

\begin{tabular}{|c|c|c|c|}
\hline Variables & Linear & Semi-log & Cobb-Douglas \\
\hline Constant & $\begin{array}{l}5316.755 \\
(0.33)\end{array}$ & $\begin{array}{l}3.800 \\
(11.00)\end{array}$ & $\begin{array}{l}0.451 \\
(0.55)\end{array}$ \\
\hline LB & $\begin{array}{l}-32.343^{\text {ns }} \\
(0.54)\end{array}$ & $\begin{array}{l}-0.0008^{n s} \\
(0.64)\end{array}$ & $\begin{array}{l}-0.079^{\text {ns }} \\
(0.434)\end{array}$ \\
\hline FD & $\begin{array}{l}105.657^{\mathrm{ns}} \\
(1.69)\end{array}$ & $\begin{array}{l}-0.054^{\mathrm{ns}} \\
(01.71)\end{array}$ & $\begin{array}{l}0.871^{* *} \\
(2.85)\end{array}$ \\
\hline FE & $\begin{array}{l}-2555.961^{\mathrm{ns}} \\
(1.61)\end{array}$ & $\begin{array}{l}-0.054^{\mathrm{ns}} \\
(1.58)\end{array}$ & $\begin{array}{l}-1.023^{\star *} \\
(2.73)\end{array}$ \\
\hline SD & $\begin{array}{l}3.9309^{\star \star \star} \\
(8.31)\end{array}$ & $\begin{array}{l}3.691^{*} \\
(3.60)\end{array}$ & $\begin{array}{l}0.790^{\star * \star} \\
(5.88)\end{array}$ \\
\hline $\begin{array}{l}\mathrm{R}^{2} \\
\text { F-stat }\end{array}$ & $\begin{array}{l}0.98 \\
30.065^{\star \star \star}\end{array}$ & $\begin{array}{l}0.88 \\
8.763^{\star \star}\end{array}$ & $\begin{array}{l}0.94 \\
19.404^{\star \star \star}\end{array}$ \\
\hline
\end{tabular}

Source: computed from field survey data (2011). ${ }^{*}$ Significant at $p<0.10 ;{ }^{* \star}$ significant at $p<0.05 ;{ }^{* \star \star}$ significant at $\mathrm{p}<0.01$; ns-not significant; value in parenthesis are standard error.

\subsection{CONCLUSION}

Based on the findings it was observed that $40 \%$ of the fish farmers in the study area were between 40 and 50 years of age and the entire fish farmers were highly educated. The study showed that fish farmers had at least between 5 and 8 years experience. All the farmers used intensive method of farming. Earthen pond was mostly preferred, followed by fibre glass and concrete pond. Majority of the famers make a gross margin of $\$ 400,000$ and $\$ 700,000$ annually. Also $89 \%$ of the farmers made profit; only $11 \%$ of the farmer did not make profit because of high total fixed cost. In the study area, the major fish domesticated was Clarias (Catfish) $61 \%$, followed by tilapia (Ladyfish) $32 \%$. Most feeds used by the farmers were brought in from other states (Oyo and Plateau) and are formulated. It was also discovered that amount spent on stocking accounted for $37.27 \%$ of the running cost, followed by amount spent on water $(30.21 \%)$, feeding (16.51\%) and labour (14.84\%). The major problem limiting improved output in the study area was high cost of input, lack of finance, access to credit facilities, theft (security) and labour problems. It can therefore be concluded that fish farming in the study area is profitable despite the high cost of running the farm and other production constraint. The sector therefore requires more support from the government and other non-governmental organization to grow sustainably.

\subsection{RECOMMENDATIONS}

There is need for establishing modern fishery hatcheries by the government in the study area to supply quality fingerlings. As most farmers had small farm sized in terms of fished stock because of high cost of fingerlings. This would reduce cost of production, reduce susceptibility to early mortality, improve the production of fast maturing fish and thereby increase general output level.

Government should establish feed mill in the study area. Because most feed used by farmers are brought in from other states (Oyo/plateau). This will assist majority of fish farmer in the Local Government of the State, reduce cost of production and increase output.

Government promotion on fish farming is inadequate therefore there is need for more public enlightenment. This was one of the major reasons why most farms were not functional.

\section{REFERENCES}


Adegeye, A. J. and Dittoh, J. S. (1985). Essentials of Agricultural Economics, Ibadan, Impact Publishers Nig. Ltd.

Adekoya, B. B. and Miller, J. W. (2004). Fish cage culture potential in Nigeria-An overview. National Cultures. Agriculture Focus. 1(5): 10.

Adewuyi, S. A., Phillip, B. B., Ayinde, I. A., and Akerele, D. (2010).Analysis of profitability of fish farming in Ogun State, Nigeria. J Hum Ecol 31(3): 179-184

Agor, G. (2007). The economics of population growth and changes in demographic structure. In MOFINEWS. Cross River State privation exercise- journey so far. Jan-Feb, 2007. 6 (3): 7.

Ajao, A.O. (2006): Economic of Fish Farming in Oyo State, Nigeria. Ph.D. Thesis, Department of Agricultural Economics. Obafemi Awolowo University, Ile-Ife, Nigeria.

Akpan, O. E. (2006). Economic of Production theory Principles and application; Wusen Publishers, Nigeria.

Anko, E. O. and Eyo, A. A. (2001). Fisheries development in Nigeria with special reference to Cross River State. Fisheries Society of Nigeria (FISON) conference proceedings. Calabar.

Anthoni, O. R. and Akinwumi, J. A. (1991). Supply and distribution of fish in Ibadan, Nigeria. Geog. J. 14(2): 16.

Blakerly, D. R. and Hrusa, C. T. (1989). Inland aquaculture development handbook, Great Britain St. Edmundsbuy press limited.

Central Bank of Nigeria (CBN). (2005). Annual Report and Statement of Accounts. Central Bank of Nigeria Publication, Abuja.

Charoff, M. (1976): Freshwater fish pond culture and management. USA.

Ele, I. E. (2008). An empirical analysis of fish production in the major fishing systems of the Cross River Basin, Nigeria. Unpublished Ph.D thesis, University of Calabar.

Elhendy, A. M. and Alzoom, A. A. (2001). Economics of fish farming in Saudi Arabia: Analysis of costs of Tilapia production. Aquaculture and Economics Management 5(34):229 - 238

El-Naggar, G., Nasr-Alla, A., and Kareem, R. O. (2008). Economic analysis of fish farming in Behera Governorate of Egypt. In: Elghobashy, H., Fitzsimmons, K., Diab, A.S. ,eds. Proceedings of 8th International Symposium on Tilapia in Aquaculture, Cairo, Egypt, 12-14 Oct 2008. Vol. 1. "From the pharaohs to the future".

Eubuomwan, G. O. (2005). Self Sufficiency in the fishery subSector: Challenges and prospects in Lagos State, CBN Research and Statistic department.

FAO (2001). Report of the eleventh session of the committee for Inland Fisheries of Africa. Abuja, Nigeria, 2427 October 2000.Nigeria, 2427 October2000. FAO Fisheries Report NO. 644. RAF1.1R644 (Bi)
FAO (2003). Supplement part presented at the workshop and Exchange of Views in fiscal reforms for fisheries. To promote growth, Poverty Eradication and sustainable management, Rome. fisheries report No: 732.

Gujarati, D. N. and Sangeetha (2007). Basic Econometrics. Tata McGraw Hill publishing company Ltd, New Delhi.

Kassali, R., Baruwa, O. I., and Mariama, B. M. (2011). Economics of fish production and marketing in urban areas of Tillabery and Niamey in Niger Republic. International Journal of Agricultural \& Rural Development. 4(2):65-71

Koutsoyiannis, A. (1977). Theory of Econometrics: An Introductory method. ( $2^{\text {nd }}$ ed). London Macmillan press Ltd.

Kudi, T. M., Bako,P. F., and Atala, T. K. (2008). Economics of fish production in Kaduna State Nigeria. ARPN Journal of Agricultural and Biological Science 3(5 \& 6):17-21

Lagos state Agricultural Development Authority (2005): Report on the status of Aquaculture in Lagos State.

Menakaya, J. C. and Floyd, B. N. (1978). Macmillan junior atlas for Nigeria. Lagos: Macmillan, 28-30.

Miller .J. (2003). Integrated Irrigation Aquaculture Opportunities in Nigeria. "The special Programme for Food Security and Rice Fish Farming in Nigeria". Document presented at the FAO Regional Integrated Irrigation Aquaculture Conference in Bamako, Mali. $4^{\text {th }}-7^{\text {th }}$ November, 2003.

Ndu N. R. 2006. Fish Farm Layout, Pond Construction, Management and Maintenance-Hatchery Techniques. A paper presented at the National Workshop on the Principles and Techniques of Fish Farming organized by Nigerian Agricultural, Cooperative and Rural Development Bank Kaduna with collaboration of Life Riches Consulting.

Quarterly news letter of the ministry of local government affairs (2006). Description of Cross River State, pp: 4-8.

Rocye, William F. (1996): Introduction to the practice of fishery science (Revised Edition); California, academic press inc.

Slang, V. C. (1973). Comparison on the Economic potential of agricultural land, animal husbandry and Oceans fisheries, the case of Aiwa Agriculture". FAO technical conference on aquaculture. Tokyo- Japan.

Shimang G.N. (2005). Fisheries Development in Nigeria, Problems and Prospects. A presentation by the Federal Director of Fisheries, in the Federal Ministry of Agriculture and Rural Development on Homestead Fish Farming Training for Serving and Retiring Public Servants in the Federal Ministry of Agriculture and Rural Development, FCT, Abuja.

Yesuf, S.A., Ashiru, A.N., and Adewuyi, S.A. (2003). Economics of Fish Farming in IbadanMetropolis. Tropical Journal of Animal Science. 5( 2): 81-88. 